\title{
THE RESPIRATION OF SOME PLANKTONIC COPEPODS
}

\section{THE EFFECT OF TEMPERATURE}

\author{
By D. T. Gauld \\ Marine Station, Millport \\ and J. E. G. Raymont \\ University of Southampton
}

(Text-figs. I, 2)

The importance of the respiratory rate of copepods in considering the food requirements of zooplankton has already been stressed (Raymont \& Gauld, I95I), and some of the factors affecting respiratory rates have been indicated. Temperature has long been recognized as one of the most important factors affecting respiration, but apparently the determinations so far made on copepods have been confined to one species, Calanus finmarchicus (cf. Marshall, Nicholls \& Orr, I935; Clarke \& Bonnet, 1939). Since, especially in neritic areas, other smaller copepods often predominate, it was felt that an investigation into the effects of temperature on some other species of copepod was necessary.

\section{MATERIALS AND METHODS}

Work was confined to three species of adult planktonic copepod, Acartia clausi Giesbrecht, ${ }^{1}$ Centropages hamatus (Lilljeborg) and Temora longicornis (Müller). The copepods were obtained from tow-nettings taken in Southampton Water, between Hamble Spit Buoy and Baldhead Buoy, an area within I-2 hr. run from the laboratory. The catch was filtered through coarse bolting silk to remove ctenophores and large medusae, well diluted and kept in breffits stored in subdued light in the cold room of the laboratory at a temperature of 5-10 ${ }^{\circ} \mathrm{C}$. Copepods were kept for at least $24 \mathrm{hr}$., sometimes for several days, in the cold room before use, in an attempt to avoid shock, and were fed with a culture of Chlamydomonas unless abundant food was present in the water. Selection of the copepods for the experiments was done as far as possible by eye, although a low-power microscope was used to a limited extent, and they were transferred from the stock breffits into crystallizing dishes of filtered Plymouth 'outside' sea water, before being put into the respirometers.

\footnotetext{
${ }^{1}$ In a few experiments some $A$. discaudata were included.
} 
Respiration measurements were made in Barcroft-Dixon constant pressure manometers as before (see Raymont \& Gauld, I95I). Five ml. of sea water were used in each flask, which normally contained 45-55 copepods, and the flasks were shaken at a speed of 100 oscillations per minute, with an amplitude of $2.5 \mathrm{~cm}$. Measurements were made either in the cold room or in the ordinary laboratory, depending on the temperature required, and in either case the flasks were immersed in a water-bath regulated to $\pm 0 \cdot 2^{\circ} \mathrm{C}$. of the selected temperature. Most of the experiments were concuucted at temperatures ranging from io to $20^{\circ} \mathrm{C}$., but some were carried out with Centropages hamatus at $6^{\circ} \mathrm{C}$.

Each experiment ran for 3-4 hr. after an equilibration period of $15 \mathrm{~min}$., and several readings were always made during the course of a run. Halfhourly readings were taken in the experiments at $20^{\circ} \mathrm{C}$., but at the lower temperatures the manometers were read only hourly. The total change was then always converted to volume of dry gas at N.T.P.

After each experiment the copepods were fixed in formalin and the identifications checked under the binocular microscope. With a few exceptions the length of the cephalothorax of the fixed animals was also measured with a micrometer eyepiece (cf. Raymont \& Gauld, I95I). Males and females were not separated in the experiments, but the number of each sex was always determined after fixation of the animals. Occasionally a few Stage V were accidentally included and sometimes one or two copepods of another species. The proportion of copepods other than adults of the selected species was always small, however. The lengths of all copepods were included in calculating the mean length for a particular run.

In two or three out of more than a hundred experiments, a nauplius or small zoea was inadvertently transferred to the experimental flask. Such animals were neglected in calculating the respiratory rates.

A very few runs showed no change in gas volume or very irregular changes and it is almost certain that leaks had occurred in the manometers. Such few runs have been disregarded.

\section{RESULTS}

Some 127 experiments were carried out altogether, and the respiratory rates, quoted as $\mu$ l. oxygen consumed per copepod per hour, of Acartia, Centropages and Temora are given in Tables I, II and III respectively. In each table the experiments done at each temperature, viz. $20,17, \mathrm{I}_{3}, 10^{\circ} \mathrm{C}$., and for Centropages $6^{\circ} \mathrm{C}$., are grouped together and the mean rate for each group is given. The mean length (cephalothorax) of the copepods used in each experiment is also indicated. Previous work (Raymont \& Gauld, I95I) showed that the respiratory rate of several species of copepods was approximately proportional to the length squared, and since the mean length of the copepods in the present investigations varied considerably from one experiment to another, a corrected 
value for the respiratory rate was calculated in the following way. The overall mean length of all animals used in all experiments was first determined for the three species. These are: Centropages, $0.882 \mathrm{~mm}$., Acartia $0.8585 \mathrm{~mm}$,

TABle I. List of ExPERIMENTS AND Respiratory Rates OBTAINED FOR ACARTIA CLAUSI

\begin{tabular}{|c|c|c|c|c|c|}
\hline $\begin{array}{l}\text { Exact } \\
\text { temp. }\end{array}$ & $\begin{array}{c}\text { Exp. } \\
\text { no. }\end{array}$ & $\begin{array}{l}\text { No. of } \\
\text { animals }\end{array}$ & $\begin{array}{l}\text { Mean } \\
\text { length } \\
(\mathrm{mm} .)\end{array}$ & $\begin{array}{c}\text { Respiration } \\
\text { rate } \\
\left(\mu \mathrm{l} . \mathrm{O}_{2} / \text { cop. } / \mathrm{hr} .\right)\end{array}$ & $\begin{array}{l}\text { Corrected } \\
\text { respiration } \\
\text { rate }\end{array}$ \\
\hline \multicolumn{6}{|l|}{$20^{\circ} \mathrm{C} .:$} \\
\hline I9.7 & I & 50 & $0.9 \mathrm{I}$ & 0.0935 & 0.083 \\
\hline I9.7 & 2 & 50 & 0.92 & 0.122 & 0.107 \\
\hline $19 \cdot 7$ & 3 & $5 I-I$ & 0.92 & 0.121 & 0.106 \\
\hline 19.7 & 4 & $50-2$ & 0.92 & 0.0935 & 0.082 \\
\hline $19 \cdot 7$ & 5 & 49 & 0.91 & 0.156 & 0.139 \\
\hline $20 \cdot I$ & 7 & 50 & 0.91 & 0.073 & 0.065 \\
\hline $20 \cdot I$ & 8 & $42-I$ & 0.93 & 0.107 & 0.092 \\
\hline $20 \cdot I$ & 9 & 45 & 0.92 & 0.098 & 0.085 \\
\hline $20 \cdot \mathrm{I}$ & IO & $46-2$ & 0.92 & 0.104 & $0.09 \mathrm{I}$ \\
\hline \multirow[t]{2}{*}{$20 \cdot I$} & I3 & $52-I$ & 0.91 & 0.106 & 0.095 \\
\hline & & & & Mean 0.107 & 0.0945 \\
\hline \multicolumn{6}{|l|}{ I $7^{\circ} \mathrm{C} .:$} \\
\hline $17 \cdot 0$ & $5 \mathrm{I}$ & 52 & 0.82 & 0.087 & 0.096 \\
\hline $17 \cdot 0$ & I I6 & $49-2$ & 0.83 & 0.073 & 0.078 \\
\hline I $7 \cdot 0$ & II 7 & $44-I$ & 0.82 & 0.088 & 0.096 \\
\hline I $7 \cdot I$ & I 22 & 46 & 0.84 & 0.052 & 0.054 \\
\hline \multirow[t]{2}{*}{ I $7 \cdot$ I } & 123 & $49-2$ & 0.84 & 0.065 & 0.069 \\
\hline & \multicolumn{5}{|c|}{$13^{\circ} \mathrm{C} .:$} \\
\hline I $3 \cdot I$ & 36 & 48 & 0.85 & 0.075 & 0.077 \\
\hline I3.I & 37 & 53 & 0.87 & 0.072 & $0.07 \mathrm{I}$ \\
\hline I3.I & 39 & 49 & 0.82 & 0.0645 & 0.070 \\
\hline I3.I & $4 I$ & 49 & 0.84 & $0.05 \mathrm{I}$ & 0.053 \\
\hline $13 \cdot 2$ & 43 & 52 & 0.85 & 0.051 & 0.052 \\
\hline 13.2 & 44 & $5 \mathrm{I}$ & 0.84 & 0.066 & 0.068 \\
\hline \multirow[t]{2}{*}{$13 \cdot 2$} & 47 & $49-I$ & 0.85 & 0.049 & 0.050 \\
\hline \multirow{2}{*}{\multicolumn{6}{|c|}{ Io ${ }^{\circ} \mathrm{C} .:$}} \\
\hline & & & & & \\
\hline I0.7 & I6 & $4 \mathrm{I}$ & 0.85 & 0.062 & 0.064 \\
\hline $10 \cdot 7$ & I7 & 46 & 0.79 & 0.069 & 0.082 \\
\hline 10.4 & 21 & $4 \mathrm{I}$ & 0.85 & 0.132 & - \\
\hline 10.4 & 22 & $45-2$ & 0.79 & 0.087 & 0.104 \\
\hline $10 \cdot 4$ & 23 & $4 \mathrm{I}$ & 0.83 & 0.086 & 0.093 \\
\hline 10.4 & 24 & 50 & 0.81 & 0.045 & 0.051 \\
\hline 10.4 & 25 & $5 \mathrm{I}$ & 0.82 & 0.0625 & 0.069 \\
\hline I0.7 & 30 & 50 & 0.83 & 0.038 & 0.040 \\
\hline $10 \cdot 7$ & $3 \mathrm{I}$ & $36-I$ & 0.83 & 0.0535 & 0.057 \\
\hline $10 \cdot 7$ & 32 & 50 & 0.83 & 0.043 & 0.047 \\
\hline \multirow[t]{2}{*}{10.4} & 98 & $53-I$ & 0.90 & 0.042 & 0.039 \\
\hline & & & & Mean 0.065 & 0.065 \\
\hline
\end{tabular}

Note. In this and the following tables any copepods dying during an experimental run are noted by a figure subtracted from the total number used.

and Temora $0.787 \mathrm{~mm}$. The respiration rate for each experiment was then multiplied by the square of this overall mean length and divided by the square of the mean length for the particular experiment. 


\section{TABLE II. List of EXPERIMENTS AND RESPIRATORY RATES OBTAINED FOR CENTROPAGES HAMATUS}

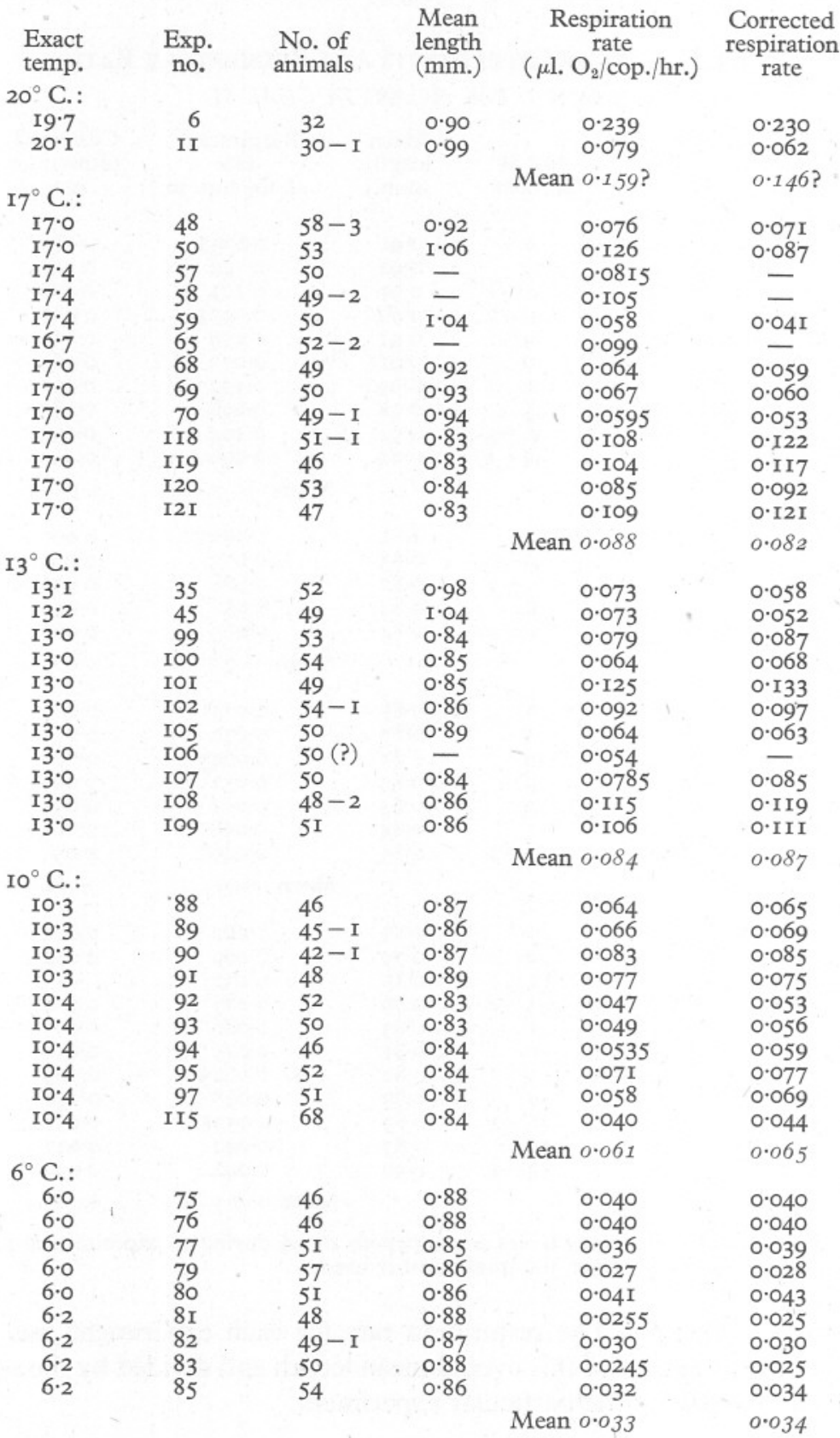


A real difficulty encountered during the course of this work was that the copepods used had to be obtained by tow-netting and that the species most commonly found varied from one haul to another. Thus in the early part of the work Acartia was very abundant with some Centropages, while towards the

TABle III. List OF EXPERIMENTS AND RESPIRATORY RATES OBTAINED FOR TEMORA LONGICORNIS

\begin{tabular}{|c|c|c|c|c|c|}
\hline $\begin{array}{l}\text { Exact } \\
\text { temp. }\end{array}$ & $\begin{array}{l}\text { Exp. } \\
\text { no. }\end{array}$ & $\begin{array}{l}\text { No. of } \\
\text { animals }\end{array}$ & $\begin{array}{r}\text { Mean } \\
\text { length } \\
(\mathrm{mm} .)\end{array}$ & $\begin{array}{c}\text { Respiration } \\
\text { rate } \\
\left(\mu 1 . \mathrm{O}_{2} / \text { cop./hr. }\right)\end{array}$ & $\begin{array}{l}\text { Corrected } \\
\text { respiration } \\
\quad \text { rate }\end{array}$ \\
\hline \multicolumn{6}{|l|}{$20^{\circ} \mathrm{C} .:$} \\
\hline 20.4 & I4 & 30 & $\mathrm{I} \cdot 03$ & 0.253 & 0.148 \\
\hline $20 \cdot 0$ & I28 & 46 & 0.71 & 0.130 & 0.161 \\
\hline \multirow[t]{2}{*}{$20 \cdot 0$} & 129 & $45-I$ & 0.70 & 0.124 & 0.156 \\
\hline & & & & Mean 0.169 & $0 \cdot 155$ \\
\hline \multicolumn{6}{|l|}{ I $7^{\circ} \mathrm{C} .:$} \\
\hline $17 \cdot 0$ & 49 & 50 & 0.95 & 0.143 & 0.098 \\
\hline $17 \cdot 4$ & 53 & $52-2$ & 0.89 & 0.089 & 0.070 \\
\hline $17 \cdot 4$ & 54 & 51 & $0.9 \mathrm{I}$ & 0.085 & 0.064 \\
\hline I7.4 & 55 & $57-I$ & - & 0.123 & - \\
\hline $17 \cdot 4$ & 56 & 48 & - & 0.120 & - \\
\hline 16.7 & $6 I$ & 50 & - & 0.115 & - \\
\hline I6.7 & 62 & 50 & - & 0.101 & - \\
\hline $16 \cdot 7$ & 63 & 49 & - & 0.112 & - \\
\hline I6.7 & 64 & $55-I$ & - & 0.149 & - \\
\hline $17 \cdot 0$ & 72 & $4 \mathrm{I}$ & 0.75 & 0.164 & 0.182 \\
\hline I $7 \cdot 0$ & 73 & $46-I$ & 0.78 & O.1I6 & 0.119 \\
\hline \multirow[t]{2}{*}{ I7 70} & 74 & 40 & $0: 8 \mathrm{I}$ & 0.120 & O.II 4 \\
\hline & & & & Mean 0.120 & $0 \cdot 108$ \\
\hline \multicolumn{6}{|l|}{$13^{\circ} \mathrm{C} .:$} \\
\hline I3.I & 38 & $40-2$ & 0.93 & $0.08 \mathrm{I}$ & 0.058 \\
\hline $13 \cdot I$ & 40 & 48 & 0.86 & 0.094 & 0.085 \\
\hline I3.I & 42 & $45-4$ & 0.92 & 0.0945 & 0.069 \\
\hline 13.0 & 103 & 47 & 0.73 & 0.1045 & $0.12 I$ \\
\hline 13.0 & 104 & $5 \mathrm{I}$ & 0.70 & 0.063 & 0.080 \\
\hline 13.0 & I IO & 50 & 0.72 & 0.074 & 0.089 \\
\hline 13.0 & III & 50 & 0.72 & 0.049 & 0.059 \\
\hline \multirow[t]{2}{*}{ I3.O } & II 2 & $5 \mathrm{I}$ & 0.71 & 0.072 & 0.088 \\
\hline & & & & Mean 0.079 & 0.081 \\
\hline \multicolumn{6}{|l|}{ I0 ${ }^{\circ} \mathrm{C} .:$} \\
\hline 10.3 & 87 & $53(?)$ & - & 0.084 & - \\
\hline 10.4 & II 3 & $59-2$ & $0.7 \mathrm{I}$ & 0.051 & 0.062 \\
\hline $10 \cdot 4$ & II 4 & 62 & 0.71 & 0.059 & 0.073 \\
\hline 10.0 & 124 & 48 & 0.72 & 0.071 & 0.085 \\
\hline 10.0 & I 25 & 44 & 0.72 & 0.099 & 0.119 \\
\hline 10.0 & 126 & $47-I$ & 0.73 & 0.063 & 0.074 \\
\hline \multirow[t]{2}{*}{10.0} & I27 & 47 & 0.72 & 0.062 & 0.075 \\
\hline & & & & Mean 0.070 & 0.081 \\
\hline
\end{tabular}

end very few Acartia were found and Temora was most abundant. Experimental runs were made with whatever material was most readily available, and therefore at some temperatures the number of experiments on one species may have been insufficient to give a reliable mean respiratory rate. Thus for Centropages at $20^{\circ} \mathrm{C}$. the mean (0.146 $\mu \mathrm{l} . \mathrm{O}_{2} / \mathrm{cop} . / \mathrm{hr}$.) (Table II) must be accepted 
with caution. With Temora (Table III) only three experiments were made at $20^{\circ} \mathrm{C}$. but here the mean of the corrected respiratory rates is $0.155 \mu \mathrm{l}$. $/ \mathrm{cop}$. $/ \mathrm{hr}$. with a S.E. of \pm 0.003 and therefore the result is significant.

\section{Table IV. The Mean Values of the Respiratory Rates}

\begin{tabular}{|c|c|c|c|c|c|}
\hline Species & $\begin{array}{l}\text { Temp. } \\
\left({ }^{\circ} \mathrm{C} .\right)\end{array}$ & $\begin{array}{l}\text { No. of } \\
\text { Exps. }\end{array}$ & $\begin{array}{l}\text { Mean } \\
\text { length }\end{array}$ & $\begin{array}{l}\text { Mean } \\
\text { respiration } \\
\text { rate }\end{array}$ & $\begin{array}{l}\text { Corrected mean } \\
\text { respiration } \\
\text { rate }\end{array}$ \\
\hline Acartia & $\begin{array}{l}20 \\
\text { I7 } \\
\text { I3 } \\
\text { I0 }\end{array}$ & $\begin{array}{r}\text { I0 } \\
5 \\
7 \\
\text { I0 }\end{array}$ & $\begin{array}{l}0.92 \\
0.83 \\
0.85 \\
0.83\end{array}$ & $\begin{array}{l}0.107 \pm 0.006 \\
0.073 \pm 0.005 \\
0.061 \pm 0.006 \\
0.059 \pm 0.0055\end{array}$ & $\begin{array}{l}0.0945 \pm 0.006 \\
0.079 \pm 0.007 \\
0.062 \pm 0.004 \\
0.065 \pm 0.007\end{array}$ \\
\hline Centropages & $\begin{array}{r}13 \\
10 \\
6\end{array}$ & $\begin{array}{l}\left\{\begin{array}{l}2 \\
\text { I3 } \\
\text { IO* }\end{array}\right. \\
\left\{\begin{array}{l}\text { II } \\
\text { IO* }\end{array}\right. \\
\text { IO } \\
9\end{array}$ & $\begin{array}{l}\overline{0.91} \\
\overline{-} \\
0.89 \\
0.85 \\
0.89\end{array}$ & $\begin{array}{l}0.159 ? \\
0.088 \pm 0.006 \\
0.086 \pm 0.0065 \\
0.084 \pm 0.007 \\
0.087 \pm 0.006 \\
0.061 \pm 0.004 \\
0.033 \pm 0.002\end{array}$ & $\begin{array}{c}0.146 ? \\
\text { - } \\
0.082 \pm 0.009 \\
0.087 \pm 0.009 \\
0.065 \pm 0.004 \\
0.034 \pm 0.002\end{array}$ \\
\hline Temora & $\begin{array}{l}20 \\
\text { I } 7 \\
\text { I3 } \\
\text { IO }\end{array}$ & $\left\{\begin{array}{c}3 \\
12 \\
6^{\star} \\
8 \\
7\end{array}\right.$ & $\begin{array}{l}0.8 I \\
0.85 \\
0.79 \\
0.72\end{array}$ & $\begin{array}{l}0.169 \pm 0.027 \\
0.120 \pm 0.007 \\
0.1195 \pm 0.011 \\
0.079 \pm 0.006 \\
0.070 \pm 0.006\end{array}$ & $\begin{array}{l}0.155 \pm 0.003 \\
0.108 \pm 0.016 \\
0.081 \pm 0.007 \\
0.081 \pm 0.007\end{array}$ \\
\hline
\end{tabular}

Table IV shows the mean respiratory rates and the means of the corrected rates for each species at each of the temperatures used. The means of the corrected rates of course omit those experiments in which the copepods were not measured and for which, in consequence, no corrected respiratory rates could be calculated. Clearly in most cases the difference between the means of the uncorrected and corrected respiratory rates is very small. The most marked exception is Temora at $20^{\circ} \mathrm{C}$. (uncorrected mean $0.169 \pm 0.027$; corrected mean $0.155 \pm 0.003)$. Table III shows that of the three experiments carried out at this temperature with Temora, one (Exp. I4) was with copepods of large size (average $\mathrm{I} .03 \mathrm{~mm}$.) and gave a high respiration rate $(0.253 \mu \mathrm{l} . / \mathrm{cop} . / \mathrm{hr}$.) while the two other experiments (Exps. I28 and 129) used small Temora (0.705 and $0.702 \mathrm{~mm}$. respectively) and the respiratory rate was greatly lowered (0.130 and $0.124 \mu \mathrm{l}$./cop./hr.). The marked effect of size on respiration even for the same stage and species of copepod is therefore well demonstrated.

\section{Discussion \\ Temora and Acártia}

The results given in Table IV show that in general an increase in respiratory rate follows a rise of temperature for all three copepods, as with other animals. For Temora and Acartia the rise from I 3 to $20^{\circ} \mathrm{C}$. is steady, though the conclusions to be drawn from the experiments at $\mathrm{Io}$ and $\mathrm{I} 3^{\circ} \mathrm{C}$. are less certain. 
Thus Table IV shows that there is apparently a small rise in mean respiratory rate for Temora between 10 and $13^{\circ} \mathrm{C}$; but when the respiratory rates are corrected for length the means are identical at these two temperatures. For Acartia, the mean corrected rate at $10^{\circ} \mathrm{C}$. is actually very slightly greater than at $\mathrm{I} 3^{\circ} \mathrm{C}$., though the difference is not significant. At these lower temperatures the relatively smaller gas-volume change probably introduces larger errors in

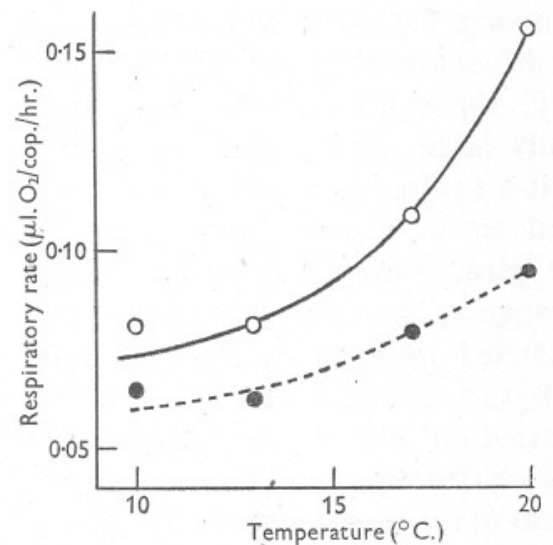

Fig. I

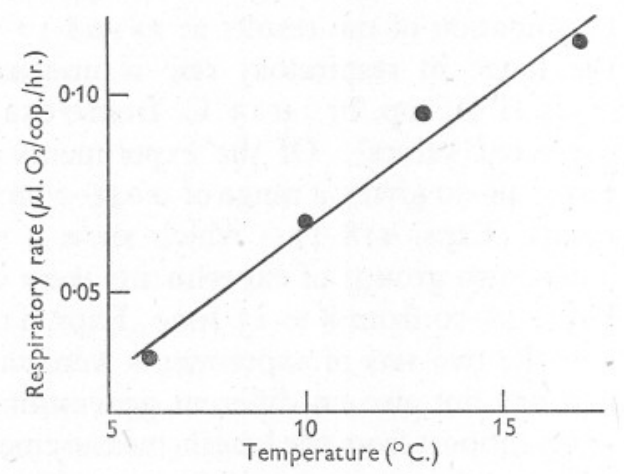

Fig. 2

Fig. I. The relation between respiratory rate and temperature. (Respiratory rate in $\mu 1 . \mathrm{O}_{2}$ per copepod per hour). $\bigcirc$ and continuous line, Temora longicornis; and pecked line, Acartia clausi.

Fig. 2. The relation between respiratory rate and temperature for the 2 nd group of Centropages hamatus.

the experiments, but as the curves given in Fig. I indicate, it seems clear that the rise in respiratory rate with temperature for both species of copepods is slower at lower temperatures and that the curves steepen from $c$. $15-20^{\circ} \mathrm{C}$. This has already been noted (cf. Zeuthen, I947) for respiration/temperature relations for a wide variety of animals, and it agrees also with the results of Marshall et al. (I935) for the copepod Calanus finmarchicus.

Fig. I also indicates, however, that the respiration of the two species of copepod is probably not affected to the same extent by the same rise in temperature. Thus while for Temora the rate between $\mathrm{Io}$ and $20^{\circ} \mathrm{C}$. is almost doubled, for Acartia the rate increases only a little over $\mathrm{I} \frac{1}{2}$ times.

These results may be compared with the temperature-respiration curve obtained by Marshall et al. (I935) for Calanus finmarchicus. They worked at temperatures down to $0^{\circ} \mathrm{C}$., and they found that between this temperature and $10^{\circ} \mathrm{C}$. the respiratory rate for male and Stage V Calanus was approximately doubled. In females the increase was considerably less $\left(0.28-0.40 \mu 1 . \mathrm{O}_{2} /\right.$ cop./hr.). Between ro and $20^{\circ} \mathrm{C}$., however, the curves for all Calanus steepen, 
and this agrees with the results here quoted for Temora and Acartia. Clarke \& Bonnet (1939) found considerable variation in the respiratory rate of Stage V Calanus, but their results indicate a rise from 0.32 to $0.91 \mu \mathrm{l} . / \mathrm{cop} . / \mathrm{hr}$. for an increase in temperature from 5.5 to $16.8^{\circ} \mathrm{C}$.

\section{Centropages}

In the experiments on Centropages there is a fairly steady increase from 6 to $13^{\circ} \mathrm{C}$., but the rate at $17^{\circ} \mathrm{C}$. (when corrected for length of animals) is slightly lower than at $13^{\circ} \mathrm{C}$., though the difference is not significant. Closer examination of the results at $\mathrm{I}_{3}$ and $\mathrm{I}^{\circ} \mathrm{C}$. shows that at both temperatures the range in respiratory rate is unusually large: at $17^{\circ} \mathrm{C}$. from $0.04 \mathrm{I}$ to 0. I $22 \mu \mathrm{l} . \mathrm{O}_{2} /$ cop. $/$ hr.; at I $3{ }^{\circ}$ C., from 0.052 to 0. $133 \mu \mathrm{l} . \mathrm{O}_{2} /$ cop. $/ \mathrm{hr}$. (see Table II, corrected values). Of the experiments at $17^{\circ} \mathrm{C}$. it is possible to separate Exps. 48-70 giving a range of $0.04 \mathrm{I}-0.087$ (mean 0.062) from the later experiments (Exps. II8-I2I) which show a range of 0.092-O.I2I (mean 0.II3). These two groups of experiments were carried out at rather different times: Exps. 48-70 from 8 to I3 June; Exps. II8-I2I on I7 July, and it is probable that the two sets of experiments were carried out not only on different townettings but also on different generations of Centropages. This idea receives some support from the length-measurements of the two groups of experimental animals; the mean of the first group (Exps. 48-70) is 0.965 , that of the second group (Exps. II8-I2I), $0.833 \mathrm{~mm}$.

Possibly the experiments at $13^{\circ} \mathrm{C}$. can also be divided into two groups. Exps. 35 and 45 were carried out on 4 and 6 June with relatively large animals (mean length I.0I4 mm.) and gave a mean respiratory rate of $0.055 \mu \mathrm{l} . \mathrm{O}_{2} /$ cop./hr., whereas Exps. 99-Io9 conducted on 2I and 22 June were concerned with smaller copepods, possibly again of a different generation (mean length $0.856 \mathrm{~mm}$.) and gave a mean rate of $0.095 \mu \mathrm{l}$. $\mathrm{O}_{2} / \mathrm{cop} . / \mathrm{hr}$.

The first group of experiments at both $\mathrm{I} 7$ and $\mathrm{I} 3^{\circ} \mathrm{C}$. appears to have been performed on similar animals (mean lengths 0.965 and I.0I4 mm.) at approximately the same time, $4-\mathrm{I}_{3}$ June. The rates for this generation at $\mathrm{I} 7$ and $\mathrm{I}_{3}{ }^{\circ} \mathrm{C}$. are 0.062 and 0.055 respectively. The second group of experiments was carried out later on a smaller generation $(0.833$ and $0.856 \mathrm{~mm}$. mean lengths), and gave rates at $\mathrm{I} 7$ and $\mathrm{I} 3^{\circ} \mathrm{C}$. of $0 . \mathrm{II} 3$ and 0.095 respectively. If either group is considered, a rise in respiratory rate with temperature is clearly indicated and the extent of the rise is of the same order ( $13 \%$ for Ist group; $18 \%$ for the 2nd group), but it is obvious that the two groups must be considered separately. If the experiments carried out at the other temperatures can be assigned to either group it should be possible to get a real relation between respiratory rate and temperature.

The results at $20^{\circ} \mathrm{C}$. cannot be seriously considered since only two experiments (which gave widely differing rates) were conducted at that temperature. At $10^{\circ} \mathrm{C}$. (Table II) nine of the ten experiments were carried out on I9-20 June, 
the last (Exp. II5) about a week later. If only the first nine experiments be considered the mean of the corrected respiration rates is 0.068 (range $0.053-0.085$ ). The mean length of the animals used in these nine experiments is $0.848 \mathrm{~mm}$., and the copepods are comparable to the second group at both $\mathrm{I} 7$ and $\mathrm{I} 3^{\circ} \mathrm{C}$. Finally, the experiments at $6^{\circ} \mathrm{C}$. were all conducted on I4-I5 June. The average length of the copepods is $0.867 \mathrm{~mm}$. and the result (mean respiration rate 0.034 ) should again be compared with those obtained from the second groups of animals at 17 and $13^{\circ} \mathrm{C}$.

Table V. The Respiratory Rates of two Groups of Centropages

\begin{tabular}{|c|c|c|}
\hline $\begin{array}{l}\text { Temp. } \\
\left({ }^{\circ} \mathrm{C} .\right)\end{array}$ & $\begin{array}{c}\text { Group I } \\
\text { (length 0.91 5 - I.044; } \\
\text { mean } 0.977 \mathrm{~mm} .)\end{array}$ & $\begin{array}{c}\text { Group II } \\
\text { (length } 0.805-0.890 ; \\
\text { mean } 0.854 \mathrm{~mm} \text {.) }\end{array}$ \\
\hline I7 & 0.062 & $0 . \mathrm{II}_{3}$ \\
\hline r3 & 0.055 (?) & 0.095 \\
\hline Io & - & 0.068 \\
\hline 6 & - & 0.034 \\
\hline
\end{tabular}

Table V shows these results for Centropages summarized. In Group I the data are obviously too scanty to permit discussion, but in Group 2 a fairly steady rise in respiratory rate follows the rise in temperature from 6 to $17^{\circ} \mathrm{C}$. These experiments should be repeated on a more homogeneous brood of Centropages, but from Fig. 2, constructed from Group 2 data, it seems clear that once again van t' Hoff's law is not strictly followed (cf. Temora, Acartia and also Calanus).

\section{Generation differences in Acartia and Temora}

It is perhaps necessary now to re-examine the data for Temora and Acartia to see whether different generations were used in the experiments with these copepods, and whether variation between experiments might be correlated with generation differences. It must be emphasized that for all three species of copepods, if respiratory rate can be correlated with generations, it cannot be explained on differences in length of the generations since all the rates have been corrected to a standard mean length.

In some cases (e.g. Acartia at $17^{\circ}$ C.) experiments were conducted several weeks apart (e.g. Exp. 5I on 8 June: Exps. II6-I23 on I7-I9 July). But in general for Acartia, the mean lengths of the copepods used (though they show some differences) and the corrected respiratory rates at any one temperature cannot clearly be separated into groups. In the experiments on Temora larger differences in the mean lengths and corrected respiratory rates were found than with Acartia, e.g. especially in the experiments at $\mathrm{I} 3^{\circ} \mathrm{C}$. But in general the range in respiratory rate found at each temperature is smaller than with Centropages and there is no obvious grouping of the experiments.

While for Temora, and possibly even for Acartia, variations attributable to 
generation differences may distort the temperature/respiration curve, the evidence for such differences is not very strong and the curves given in Fig. I may be regarded therefore as showing a true relation between temperature and respiration for these copepods during June and July. It is still probable that different generations of these copepods at other seasons of the year might show very appreciable differences in respiratory rate, and a few preliminary experiments on Temora by one of us (J.E. G.R.) during the autumn give some support to this suggestion.

Differences in the respiratory rates of different generations might be suggested as an explanation of the puzzling results obtained previously with Centropages typicus (Raymont \& Gauld, I95I). With this copepod it may be recalled that the experimental data fell clearly into two well-marked groups, one giving a mean respiratory rate of $0.29 \mu \mathrm{l}$. $\mathrm{O}_{2} / \mathrm{cop}$. $/ \mathrm{hr}$., the second group the much lower mean of $0.18 \mu \mathrm{l}$./cop. $/ \mathrm{hr}$. Differences such as time of keeping in the laboratory, feeding, and varying proportions of the sexes could not be correlated with these two groups. All the copepods used in these experiments were taken in one week ( $7-\mathrm{I}_{3}$ September 1949), so that the different respiration rates observed cannot be attributed to the use of different generations. But the copepods may have been taken from different populations since tow-nettings were taken both off Garroch Head, to the westward, and in Fairlie Channel, to the eastward of Cumbrae; unfortunately no records were kept of where the copepods used in any particular experiment were caught.

\section{Sex and Respiration Rate}

Marshall et al. (1935) have shown that male and female Calanus finmarchicus respire at different rates and are affected to different degrees by rising temperature. Since in the experiments here described male and female copepods were not separated, the suggestion might be made that variations in the respiratory rate, and in particular the variations seen for Centropages at 17 and $13^{\circ} \mathrm{C}$., were due to different numbers of the sexes being used for experiments rather than different generations being employed.

The first group of experiments with Centropages at $17^{\circ} \mathrm{C}$. (Exps. 48-70) together give a much lower proportion of females (56\% group (Exps. II8-I2I) in which over 90\% were females. If, therefore, female Centropages respire more actively than males (though this is contrary to the findings of Marshall et al., I935, for Calanus), the higher respiratory rate in the second group of experiments at both temperatures might be attributed to the greater proportion of females. But reference to individual experiments at these temperatures shows that the suggestion is unsound. Thus at $17^{\circ} \mathrm{C}$., in Exp. 48 , with a great preponderance of males the respiratory rate was $0.07 \mathrm{I} \mu \mathrm{l} . \mathrm{O}_{2} / \mathrm{cop}$. $/ \mathrm{hr}$., Exp. 69 with practically equal numbers was 0.060 and in Exp. 70, with three times as many females as males, it was 0.053 , exactly the opposite of what would be expected. 
While, therefore, differences may exist between the respiration of male and female Centropages hamatus the marked variation between the two groups of experiments at both $\mathrm{I} 7$ and $13^{\circ} \mathrm{C}$. cannot be explained in this way. And indeed the possibility that instead we were really dealing with different generations of copepods is strengthened by the different proportion of the sexes used in the experiments. For example, it has already been pointed out that at $17^{\circ} \mathrm{C}$. the second group of experiments (Exps. II8-I2I) has a much higher proportion of females (more than $90 \%$ ) than the earlier first group (Exps. 48-70) with only 56\% females. But since female $C$. hamatus are somewhat larger than males (cf. Sars, I903; Marshall, I949) the mean lengths of the copepods used in Exps. II8-I2I would be expected to be greater than in Exps. 48-70. In fact the copepods used in Exps. II8-I2I were definitely smaller than those used in earlier experiments, and it is therefore even more probable that they belonged to a different generation. Marshall (I949) has shown that the length of Centropages (Stage VI) decreases to a minimum about July and August.

\section{Length and Respiratory Rate}

Experiments on a number of species and stages of copepods have suggested that respiratory rate can be expressed as a function of the length (Raymont \& Gauld, I95I) in the equation

$$
\log R=2 \cdot \text { I9 } \log L-0.928 \text {, }
$$

where $R=$ respiratory rate at $17^{\circ} \mathrm{C}$., and $L=$ length of cephalothorax. It is of interest to see whether the present determinations on Centropages, Acartia and Temora will also fit this suggested relationship. Table VI gives the lengths, mean corrected respiratory rates and the respiratory rates calculated from the equation quoted above.

\section{Table VI. The Calculated Respiratory Rates AND THE ACTUAL RATES OBTAINED}

$\begin{array}{lccc}\text { Species } & \begin{array}{c}\text { Mean length } \\ (\mathrm{mm} .)\end{array} & \begin{array}{c}\text { Corrected } \\ \text { respiration } \\ \text { rate }\end{array} & \begin{array}{c}\text { Calculated } \\ \text { respiration } \\ \text { rate }\end{array} \\ \text { Centropages } & 0.882 & 0.082 & 0.090 \\ \text { Acartia } & 0.8585 & 0.079 & 0.085 \\ \text { Temora } & 0.787 & 0.108 & 0.070\end{array}$

The agreement between the observed and calculated respiratory rates is reasonably good for Centropages and Acartia, but for Temora the calculated rate (0.070) is considerably lower than the result obtained experimentally (0.108), and therefore, in contrast to Centropages and Acartia, it would appear that the suggested respiration/length relationship is only roughly applicable to Temora.

Probably one of the real factors determining the respiratory rate is surface area, and the length squared may be regarded as a measure of surface. A 
numerical ratio between the square of the length of a copepod and its surface area can be calculated if its cephalothorax is matched by a simple geometrical form. ${ }^{1}$ While Calanus, Acartia and Centropages have elongate, oblong cephalothoraces which can be closely matched by a cylinder with a hemisphere at each end, that of Temora is relatively short and swollen anteriorly and can best be matched by two cones lying base to base, the longer one which forms the posterior part of the cephalothorax having its apex truncated. Euchaeta is more irregular in shape and the ratio quoted below was calculated by summation of a series of cylinders and parts of cones. From these forms the following ratios between the square of the length and surface area were calculated:

\begin{tabular}{llll}
\multicolumn{1}{c}{ Species } & $L^{2} / S$ & \multicolumn{1}{c}{ Species } & $L^{2} / S$ \\
Calanus finmarchicus & $\mathrm{I} \cdot 03$ & Centropages hamatus & 0.92 \\
Euchaeta norvegica & $\mathrm{I} \cdot \mathrm{I} 3$ & Acartia clausi & $\mathrm{I} \cdot \mathrm{I9}$ \\
Centropages typicus & 0.96 & Temora longicornis & 0.72
\end{tabular}

It can be seen that in all the species except Temora the ratio is nearly I, so that length squared is a fairly good measure of the surface area. That for Temora is much lower and its length must be multiplied by $\mathrm{I} \cdot 2$ before squaring to make it an equivalent measure of surface area. If the respiration rate of Temora is now calculated using $\mathrm{I} \cdot 2 \mathrm{~L}$ instead of $L$, a value of $0.106 \mu \mathrm{l}$./ cop. $/ \mathrm{hr}$. is obtained which agrees very well with the experimental result.

\section{General Conclusions}

There remains the very difficult question as to how far results obtained from laboratory experiment may be applied to conditions in the sea. It is likely that the shaking of the apparatus and the concentration of some fifty small copepods in about $5 \mathrm{ml}$. of sea water for some hours may stimulate and excite the animals, so leading to a respiratory rate that is considerably higher than that under natural conditions (cf. Raymont \& Gauld, I95I). But even if the rate quoted here for any given temperature is higher than in the sea, it is probable that a rise in respiration with temperature will follow in the sea just as in the laboratory. Temperatures of around $20^{\circ} \mathrm{C}$. will certainly not be experienced in British waters, but a rise of $9-10^{\circ} \mathrm{C}$. (say from 6 to $15^{\circ} \mathrm{C}$.) between late winter and late summer is not unlikely in inshore surface waters and more striking temperature variations occur in a sea area like the Gulf of Maine. Riley (I946), for instance, quotes the mean temperature for the upper $30 \mathrm{~m}$. as varying from $2.6^{\circ} \mathrm{C}$. in March to $15.2^{\circ} \mathrm{C}$. in September over Georges Bank (cf. also Riley, 1947, fig. 29).

1 The surface area so calculated is not the true surface area, since the surfaces of the urosome and the appendages have been ignored; in consequence the ratios given above have no absolute significance. But the calculated surface area probably bears a reasonably constant relationship to the real surface area so that the ratios quoted are valid for comparative purposes, as they are used here. 
Estimates of the food required by planktonic copepods have been made by Marshall et al. (1935), Clarke \& Bonnet (1939), Riley (I947) \& Harvey (1950). These workers based their calculations on the respiratory rate of Calanus finmarchicus measured by Clarke \& Bonnet (1939) or Marshall et al. (I935), and tried to relate these requirements to the amount of available food in the sea. Measurements of the respiration rate of other species (Raymont \& Gauld, I95I, and the present results) suggest that such estimates must be modified in at least two directions.

First, it has been shown that the respiratory rate of copepods is approximately proportional to the square of the length, probably because its magnitude is determined by the surface area of the animals. Now all the estimates referred to above express the food requirements as a percentage of the weight of the animal, giving values ranging from 2 to $8 \%$ at different temperatures. Since the weight is roughly proportional to the cube of the length while respiratory rate, and so metabolic food requirements, are proportional to the square of the length, the metabolic food requirements expressed as a percentage of the weight will be inversely proportional to the length. In consequence, estimates of the food requirements of Calanus cannot be directly applied to other species or to mixed populations, and to estimate the food requirements of a population of copepods one must know not only the total weight of the population but also the size distribution of the copepods making up that population.

Secondly, in discussing seasonal variations in the respiratory food requirements, these authors have assumed that temperature is the only factor affecting the respiratory rate. The measurements of the respiratory rate of Centropages described here apparently show that different generations of the same species may have different respiratory rates (apart from differences related to size differences of generations at the same temperature). If such generation differences should prove to be more wide-spread, then in addition to an increase in food requirements during summer and a decrease in winter produced by seasonal changes in temperature, further changes, at present unknown, in the food requirements of different generations will have to be taken into account.

\section{SUMMARY}

The respiratory rates of three species of planktonic copepods, Acartia clausi, Centropages hamatus and Temora longicornis, were measured at four different temperatures.

The relationship between respiratory rate and temperature was found to be similar to that previously found for Calanus, although the slope of the curves differed in the different species.

The observations on Centropages at $\mathrm{I} 3$ and $\mathrm{I}^{\circ} \mathrm{C}$. can be divided into two groups and it is suggested that the differences are due to the use of copepods from two different generations. 
The relationship between the respiratory rates and lengths of Acartia and Centropages agreed very well with that previously found for other species. That for Temora was rather different: the difference is probably due to the distinct difference in the shape of the body of Temora from those of the other species.

The application of these measurements to estimates of the food requirements of the copepods is discussed.

\section{REFERENCES}

Clarke, G. L. \& Bonnet, D. D., I939. The influence of temperature on the survival, growth and respiration of Calanus finmarchicus. Biol. Bull. Woods Hole, Vol. 76, pp. $37 \mathrm{I}-83$.

HaRvey, H. W., I950. On the production of living matter in the sea off Plymouth. fourn. Mar. Biol. Assoc., Vol. 29, pp. 97-137.

Marshall, S. M., Nicholls, A. G. \& OrR, A. P., I935. On the biology of Calanus finmarchicus. Part VI. Oxygen consumption in relation to environmental conditions. Fourn. Mar. Biol. Assoc., Vol. 20, pp. I-27.

MARShall, S. M., I949. On the biology of the small copepods in Loch Striven. fourn. Mar. Biol. Assoc., Vol. 28, pp. 45-I22.

Raymont, J. E. G. \& Gauld, D. T., I95I. The respiration of some planktonic copepods. Fourn. Mar. Biol. Assoc., Vol. 29, pp. 681-93.

RILEY, G. A., I946. Factors controlling phytoplankton populations on Georges Bank. Fourn. Mar. Res., Vol. 6, pp. 54-73.

- 1947. A theoretical analysis of the zoo-plankton population of Georges Bank. fourn. Mar. Res., Vol. 6, pp. I04-I3.

Sars, G. O., I903. An account of the Crustacea of Norway. Vol. IV. Copepoda Calanoida. Bergen.

ZeUtheN, E., I947. Body size and metabolic rate in the animal kingdom with special regard to the marine micro-fauna. Compt. Rend. Lab. Carlsberg, Ser. Chim., T. 26, (No. 3), pp. 17-I6I. 